\title{
Sulodexide Slows Down the Senescence of Aortic Endothelial Cells Exposed to Serum from Patients with Peripheral Artery Diseases
}

\author{
Patrycja Sosińska-Zawierucha ${ }^{a}$ Beata Maćkowiak ${ }^{a}$ Ryszard Staniszewski ${ }^{b}$ \\ Katarzyna Sumińska-Jasińska ${ }^{a} \quad$ Magdalena Maj $^{b} \quad$ Zbigniew Krasińskib $^{b}$ \\ Andrzej Bręborowicz ${ }^{\mathrm{a}}$ \\ ${ }^{a}$ Department of Pathophysiology, Poznan University of Medical Sciences, ${ }^{b}$ Department of Vascular and \\ General Surgery, Poznan University of Medical Sciences, Poland
}

\section{Key Words}

Human arterial endothelial cells $•$ Senescence $\cdot$ Atherosclerosis $\bullet$ Sulodexide

\begin{abstract}
Background/Aims: Aging of the arterial endothelial cells results in the appearance of their inflammatory phenotype, which may predispose patients to the acceleration of arteriosclerosis. We studied the effect of serum from patients with peripheral artery disease (PAD) on the senescence of human aortic endothelial cells (HAEC) and how that process is modulated by sulodexide. Methods: HAEC replicative aging in vitro was studied in the presence of $10 \%$ PADserum (PAD Group) or10\%PAD serum and Sulodexide $0.5 \mathrm{LRU} / \mathrm{mL}$ (PAD-SUL group). In control group cells were cultured in medium supplemented with $10 \%$ fetal bovine serum. All studied parameters were evaluated at the beginning and at the end of the study, in all experimental groups. Population doubling time (PDT) was studied from the cells growth rate after repeated passages, and senescence-associated beta- galactosidase activity (SA- $\beta$ gal activity) was measured with the fluorescence flow cytometry. Expression of IL6, vWF, p21 and p53 genes was measured with the real-time polymerase chain reaction (Real-Time PCR). Concentrations of IL6 and VWF were measured with the standard ELISA kits. Results: PAD serum accelerated the senescence of HAEC as reflected by increased, compared to control, expression of the IL6 gene $(+43 \%, p<0.05)$ VWF gene $(+443 \%, p<0.01)$, p21 gene $(+124 \%, p<0.01)$ and $p 53$ gene $(+$ $85 \%, p<0.01)$. Secretion of IL6 and vWF was higher in that group: $+101 \%, p<0.01$ and $+78 \%$, $\mathrm{p}<0.01$, respectively, as compared to control. Also, SA- $\beta$ gal activity was higher in the PAD group $(+33 \%, p<0.05)$ than in the control group. In the PAD group PDT was longer $(+108 \%$, $\mathrm{p}<0.01$ ) as compared to control. Simultaneous use of Sulodexide with PAD serum significantly reduced all the above described senescent changes in HAEC. Conclusions: PAD serum accelerates the aging of HAEC which may result in the faster progression of arteriosclerosis. Sulodexide reduces PAD induced senescence of HAEC, which results in lower inflammatory and thrombogenic activity of these cells.

(C) 2018 The Author(s)

Published by S. Karger AG, Basel

Prof. Andrzej Bręborowicz

Department of Pathophysiology

Poznan University of Medical Sciences

E-Mail abreb@ump.edu.pl
\end{abstract}

\section{KARGER}




\section{Introduction}

Dysfunction of the arterial endothelial cells results in altered intravascular homeostasis which predisposes patients to the progression of atherosclerotic changes. Inflammation and oxidative stress are the main disorders which contribute to impaired function of the vascular endothelium [1]. Cellular senescence, which is a natural process, being parallel t body aging, also happens in the endothelial cells and accelerates the formation of atherosclerotic changes [2]. Hayflick state that cells in in vitro culture have limited ability to replicate [3], and later it was shown that progressive loss of telomeres during repeated replication is responsible for that effect [4]. Cells which become senescent not only have reduced ability to proliferate, but also develop the senescence-associated secretory phenotype, which results in the increased expression and secretion of the inflammatory mediators, growth factors and proteases [5].

Senescence of the endothelial cells is not only due to shortening of their telomeres but may also be induced by such factors as high glucose, Angiotensin II or oxidative stress [6, 7, 8]. These factors play an important role in various types of pathologies of the cardiovascular system in humans. Warboys described the presence in aortae from healthy pigs of enhanced senescence-associated $\beta$-galactosidase staining at sites of the disturbed blood flow [9]. The presence of senescence-associated $\beta$-galactosidase (SA- $\beta \mathrm{Gal}$ ) was also detected in the endothelium lining atherosclerotic human arteries [10]. Slowing down endothelial senescence may be a potential approach in the prevention of arterial atherosclerosis. The protective action towards the endothelial cells of some drugs such as ACE inhibitors and antioxidant agents may be linked with their antisenescent activity [11].

Glycosaminoglycans are the component of the endothelial glycocalyx regulating interactions between the cells and the intravascular space [12]. Damage to the endothelial glycocalyx is an important factor initiating the process of atherosclerosis [13]. It was shown that the age-related reduced ability of the endothelial progenitor cells to migrate is linked with the alteration in the structure of heparan sulphate proteoglycans located in the glycocalyx [14]. Previously, we found that sulodexide, which is a mixture of low molecular weight heparin and dermatan sulphate, reduces the senescence of human venous endothelial cells in in vitro conditions [15]. Recently, we described the protective effect of sulodexide against the proinflammatory action of serum from patients with peripheral artery disease (PAD) towards human aortic endothelial cells [16]. In the present paper we present results from the experiments in which the effect of sulodexide on the aging of human aortic endothelial cells exposed chronically to serum from patients with PAD was evaluated.

\section{Materials and Methods}

Experiments were performed on human aortic endothelial cells (HAEC) obtained from Life Technologies Corporation (Carlsbad, USA). Cells were maintained in standard conditions of the in vitro culture in air atmosphere with $5 \% \mathrm{CO}_{2}$ at $37^{\circ} \mathrm{C}$. Culture was established in medium M200 supplemented with $2 \%$ foetal bovine serum, hydrocortisone $1 \mu \mathrm{g} / \mathrm{ml}$, heparin $10 \mu \mathrm{g} / \mathrm{ml}$, human epidermal growth factor $10 \mathrm{ng} / \mathrm{ml}$ and basic fibroblast growth factor $3 \mathrm{ng} / \mathrm{ml}$.

During the experiments we evaluated the effect of serum from patients with PAD (III or IV Fontaine stage) on the replicative aging of HAEC. The study was approved by the University Bioethical Committee. Sera obtained from 10 patients were pooled (PAD serum) and used during the study. Replicative senescence of the endothelial cells was performed according to the standard method used in our lab [17]. In the experimental groups, during the whole study, the following media were used:

A. Control group - standard culture medium supplemented with $10 \% \mathrm{FBS}$

B. PAD Serum group - standard culture medium supplemented with $10 \%$ PAD serum

C. PAD Serum - Sulodexide group - standard culture medium supplemented with $10 \%$ PAD serum and Sulodexide $0.5 \mathrm{LRU} / \mathrm{mL}$

In all groups experiment was started with the cells from the second passage. 


\section{Cellular Physiology Cell Physiol Biochem 2018;45:2225-2232 \begin{tabular}{l|l} 
and Biochemistry Published online: March 15, 2018 & $\begin{array}{l}\text { (c) } 2018 \text { The Author(s). Published by S. Karger AG, Basel } \\
\text { www.karger.com/cpb }\end{array}$
\end{tabular}}

\section{Induction of cellular senescence in vitro}

The senescence of HAEC was induced by serial passaging at 7-day intervals for 10 weeks. Cells were seeded into $25 \mathrm{~cm}^{2}$ flasks at density $3 \times 10^{3} / \mathrm{cm}^{2}$. At each subcultivation, the cells were counted and the population doubling time (PDT) was estimated according to the following formula: $\mathrm{PDT}=\ln 2 /\left[\ln \left(\mathrm{N} / \mathrm{N}_{0}\right) / \mathrm{t}\right]$ where $\mathrm{N}$ indicates the number of cells harvested at the end of the incubation, $\mathrm{N}_{0}$ - number of cells seeded and $t$ - time of culture.

At the beginning of the study and after 10 weeks cells were also seeded into 6 wells plates for analysis of genes expression, and into 24 wells plates for evaluation of their secretory activity. Also SA- $\beta$ Gal activity in the cells was measured with fluorescence analysis. Additionally, at the end of the study the ability of the cells from all experimental groups to proliferate in standard culture was evaluated.

\section{Analysis of gene expression}

Experiments were performed on HAECs monolayers in 6-well plates, at the beginning of the study and after 10 weeks of cellular replicative aging. Cell monolayers were incubated for 24 hours in the following media:

- $\quad$ Standard culture medium supplemented with 10\% FBS

- $\quad$ Standard culture medium + 10\% PAD serum

- $\quad$ Standard culture medium + 10\% PAD serum + Sulodexide $0.5 \mathrm{LRU} / \mathrm{mL}$

After exposition, total RNA from the cells was isolated using the ReliaPrep ${ }^{\mathrm{TM}}$ RNA Cell Miniprep System (Promega, USA) method according to the manufacturer's instruction. RNA samples were treated with DNase I using DNA-free DNase Treatment and Removal Reagent (Ambion). RNA quality and concentration were assessed by spectrophotometry using a NanoDrop (NanoDrop, Thermo Scientific, DE, USA).

One microgram of total RNA was reverse-transcribed to cDNA using the Transcriptor First Strand cDNA Synthesis Kit (Roche, Switzerland). Relative levels of the mRNA of 4 genes: Interleukin -6 [IL6], Von Willebrand factor [VWF], Tumour protein p53 [p53] and Cyclin-dependent Kinase Inhibitor 1 [p21] were analyzed using Sybr green real-time quantitative PCR (Applied Biosystems) in triplicates and normalized to levels of internal house-keeping genes: Glyceraldehyde-3-phosphate Dehydrogenase (GAPDH) and Hypoxanthine Phosphoribosyltransferase 1 (HPRT)

Specific primers for the amplification of each gene were designed using Primer-BLAST [18]. Primer characteristics are presented in Table 1. The PCR parameters were as follows: initial denaturing for $10 \mathrm{~min}$ at $95^{\circ} \mathrm{C}$, followed by 35 cycles of denaturation $\left(95^{\circ} \mathrm{C}\right.$ for $\left.10 \mathrm{~s}\right)$, annealing $\left(56^{\circ} \mathrm{C}\right.$ for $\left.45 \mathrm{~s}\right)$ and extension $\left(60^{\circ} \mathrm{C}\right.$ for $20 \mathrm{~s}$ ). After completed real-time PCR reactions, a melting curve analysis was performed for each sample to confirm that a single, specific product was generated. Relative gene expression was calculated using the 2- $\Delta \Delta$ Ct method [19].

\section{Evaluation of the HAEC secretory activity.}

At the beginning and at the end of the study cells were seeded into 24-wells plates and grown in media adequate for each group until they reached monolayers. Then 24 hour incubation in the studied media was performed. Afterwards in all groups cells were exposed in standard culture medium, with 2\%FBS for 24 hours to evaluate their secretory activity. At the end of the incubation supernatant was collected for further measurements of IL6 (ELISA kit, R\&D, Minneapolis, USA) and vWF (ELISA kit, Sigma-Aldrich, St. Louis, USA) concentration. Cells were detached with trypsin $0.05 \%$ - EDTA $0.02 \%$ solution, and the number of cells in each well was counted in a hemocytometer.

\section{Proliferation of HAEC}

After 10 weeks of replicative aging, cells from each group were seeded in 24-well plate in a standard culture medium (8 wells per group). After 24 hours when the cells were attached to the bottom of the well, the medium was
Table 1. Characteristic of the primers used in the study

\begin{tabular}{|c|c|c|c|c|}
\hline Gene & Name & Gene ID & Amplicon length (bp) & Primer sequence $\left(5^{\prime} \rightarrow 3^{\prime}\right)$ \\
\hline GAPDH & Glyceraldehyde-3-phosphate Dehydrogenase & 2597 & 231 & $\begin{array}{c}\text { F:TTCGTCATGGGTGTGAACC } \\
\text { R:GATGATGTTCTGGAGAGCCC }\end{array}$ \\
\hline HPRT & Hypoxanthine Phosphoribo-syl-transferase 1 & 3251 & 192 & $\begin{array}{l}\text { F: TGCTCGAGATGTGATGAAGG } \\
\text { R: TCCCCTGTTGACTGGTCATT }\end{array}$ \\
\hline IL6 & Interleukin 6 & 3569 & 264 & $\begin{array}{l}\text { F:ATGAACTCCTTCTCCACAAGC } \\
\text { R:GTTTTCTGCCAGTGCCTCTTTG }\end{array}$ \\
\hline VWF & Von Willebrand factor & 7450 & 232 & $\begin{array}{l}\text { F:CCAGATTTGCCACTGTGATG } \\
\text { R:AAAGGCCTTCAGCACTTCAA }\end{array}$ \\
\hline p53 & Tumor protein p53 & 7157 & 99 & $\begin{array}{l}\text { F:TTGCAATAGGTGTGCGTCA } \\
\text { R:TCCCCACAACAAAACACCAG }\end{array}$ \\
\hline p21 $1^{\text {cip1 }}$ & Cyclin-dependent Kinase Inhibitor 1 & 1026 & 113 & $\begin{array}{l}\text { F:TGATTAGCAGCGGAACAAGG } \\
\text { R:TGCCAGGAAAGACAACTACTCC }\end{array}$ \\
\hline
\end{tabular}




\section{Cellular Physiology Cell Physiol Biochem 2018;45:2225-2232 \\ and Biochemistry Published onine: Varch 15, 2018 \begin{tabular}{l|l} 
DOI: 10.1159/000488167 & $\begin{array}{l}\text { C } 2018 \text { The Author(s). Published by S. Karger AG, Basel } \\
\text { www.karger.com/cpb }\end{array}$
\end{tabular} \\ Sosińska-Zawierucha et al.: Endothelial Senescence and Sulodexide}

replaced with the standard culture medium + 2\% FBS supplemented with ${ }^{3} \mathrm{H}$ - methyl thymidine (SigmaAldrich, St. Louis, USA) in an amount sufficient to obtain the final concentration of the isotope of $2 \mu \mathrm{Ci} /$ mL. HAEC were cultured in the presence of ${ }^{3} \mathrm{H}$ - methyl thymidine for 24 hours, and then the medium was removed, and cells were harvested from the wells with trypsin $0.05 \%$ - EDTA $0.02 \%$ solution and precipitated with 10\% trichloroacetic acid (TCA). The cell precipitate was washed twice with TCA and lysed with $0.1 \mathrm{~N}$ $\mathrm{NaOH}$. Radioactivity of the lysed cell precipitate was measured in a $\beta$-counter, and its value reflected the amount of the radiolabelled thymidine incorporated into the DNA of the proliferating cells.

\section{Fluorescence detection of SA- $\beta$ gal activity}

The quantitative assessment of the senescence-associated beta-galactosidase activity was performed using flow-cytometry analysis according to the Debacq-Chainiaux et al. protocol [20]. Briefly, cells were seeded in 6-well culture plates and incubated with $100 \mathrm{nM}$ bafilomycin A1 for $1 \mathrm{~h}$ in fresh cell culture medium at $37^{\circ} \mathrm{C}$ and $5 \% \mathrm{CO}_{2}$. After lysosomal alkalinization, the fluorogenic substrate for $\beta$-galactosidase $\left(\mathrm{C}_{12} \mathrm{FDG}\right.$, dodecanoylaminofluorescein di- $\beta$-D-galactopyranoside) was added to the culture medium to the final concentration of $33 \mu \mathrm{M}$ and incubated for an additional $2 \mathrm{~h}$. After the incubation, the solution was removed and the cell monolayers were washed twice for $40 \mathrm{~s}$ with $2 \mathrm{ml}$ of PBS at room temperature. Afterwards the cells were harvested with trypsin $0.05 \%$-EDTA $0.02 \%$ solution, counted and subjected to flow-cytometry analysis using FACS ARIA III (Becton-Dickinson, USA). An appropriate negative control was used to determine the level of autofluorescence. The determination of positive cells was carried out on a two-parameter display of FSC versus $\mathrm{C}_{12}$-FL (FITC/488nm).

\section{Statistical analysis}

Results are presented as mean \pm SD. Analysis of the data was performed with one way analysis of variance, with the post hoc Newman Keuls test. A p value less than 0.05 was considered significant.

\section{Results}

Repeated 10 passages of HAEC from the control group resulted in their senescence as reflected by hypertrophy of the cells, increased accumulation of SA- $\beta-$ Gal $(+643 \%$, $\mathrm{p}<0.0001)$, and prolongation of their PDT $(+46 \%)$. Also we observed increased expression of genes for IL6 $(+280 \%, \mathrm{p}<0.001)$ and vWF $(+200 \%)$ as well as increased secretion of these compounds from the cells, by $31 \%, \mathrm{p}<0.01$ and by $46 \%, \mathrm{p}<0.01$, respectively. Expression of genes responsible for the process of cellular senescence was also increased: p53 (+30\%) and p21 (+110\%), as compared to the beginning of the study.

Senescence of the cells replicated in the presence of PAD serum was stronger than in control. The addition of Sulodexide $(0.5 \mathrm{LRU} / \mathrm{mL})$ resulted in a weaker prosenescent effect of PAD serum. Mean values of PDT for cells exposed to PAD serum was higher by $108 \%$, $\mathrm{p}<0.0001$ vs. control and by $72 \%, \mathrm{p}<0.05$ vs. cells treated simultaneously with Sulodexide (Fig. 1). HAEC exposed for 10 weeks to PAD serum had weaker ability to proliferate in standard culture conditions: - $21 \%$ vs. control, $\mathrm{p}<0.01$ and $-26 \%$ vs. cells treated with PAD serum and Sulodexide $\mathrm{p}<0.05$. (Fig. 2). HAEC chronically exposed to PAD serum had a higher increase of SA- $\beta$-Gal activity than cells from the control group $(+33 \%, \mathrm{p}<0.05)$ or cells treated with PAD serum and Sulodexide (+44\%, p<0.01) (Fig. 3).

After 10 weeks of the replicative aging cells exposed to PAD serum showed higher expression of genes for IL6 (+43\%, p<0.05), vWF $(+443 \%, p<0.01)$, p21 $(+124 \%, p<0.01)$ and p53 (+85\%, p<0.01) than cells cultured in control medium. The addition of Sulodexide prevented PAD-serum induced changes of the above listed genes expression in HAEC undergoing replicative aging (Fig. 4). In the case of p21 and p53 genes, their expression after exposure to PAD serum but supplemented with Sulodexide was lower than in the control group (respectively $-53 \%$, $\mathrm{p}<0.05$ and $-38 \%$, $\mathrm{p}<0.05$ ).

The secretion of IL6 studied at the end of the experiment was highest in the PAD group, as compared to control $(+101 \%, \mathrm{p}<0.01)$ and the Sulodexide group $(+104 \%, \mathrm{p}<0.01)$. The same effect was observed for vWF, where the synthesis of that molecule in cells from the PAD 


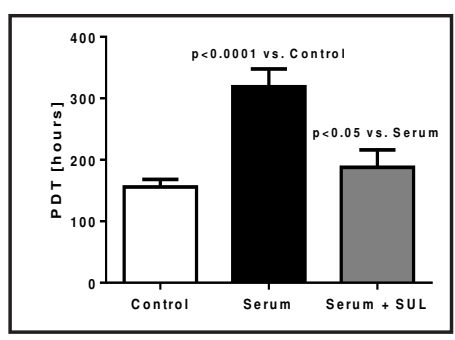

Fig. 1. Population doubling time, after 10 weeks of the experiment, in control group (Control), cells exposed to PAD serum (Serum) and cells exposed to PAD serum + Sulodexide 0.5 LRU/mL (SerumSUL).

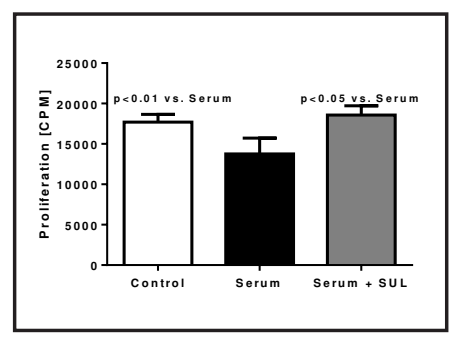

Fig. 2. Proliferation of HAEC, in standard culture medium $+2 \%$ FBS, after 10 weeks of replicative aging in standard culture medium (Control) to medium supplemented with PAD serum (Serum) and to medium supplemented with PAD serum and Sulodexide 0.5 LRU/mL.

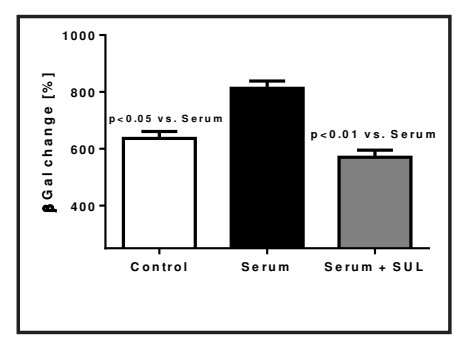

Fig. 3. Relative change, vs. start of the experiment, of SA$\beta$-Gal activity in control group (Control) and in cells exposed to PAD serum (Serum) or PAD serum and Sulodexide 0.5 LRU/ $\mathrm{mL}$ (Serum+SUL).

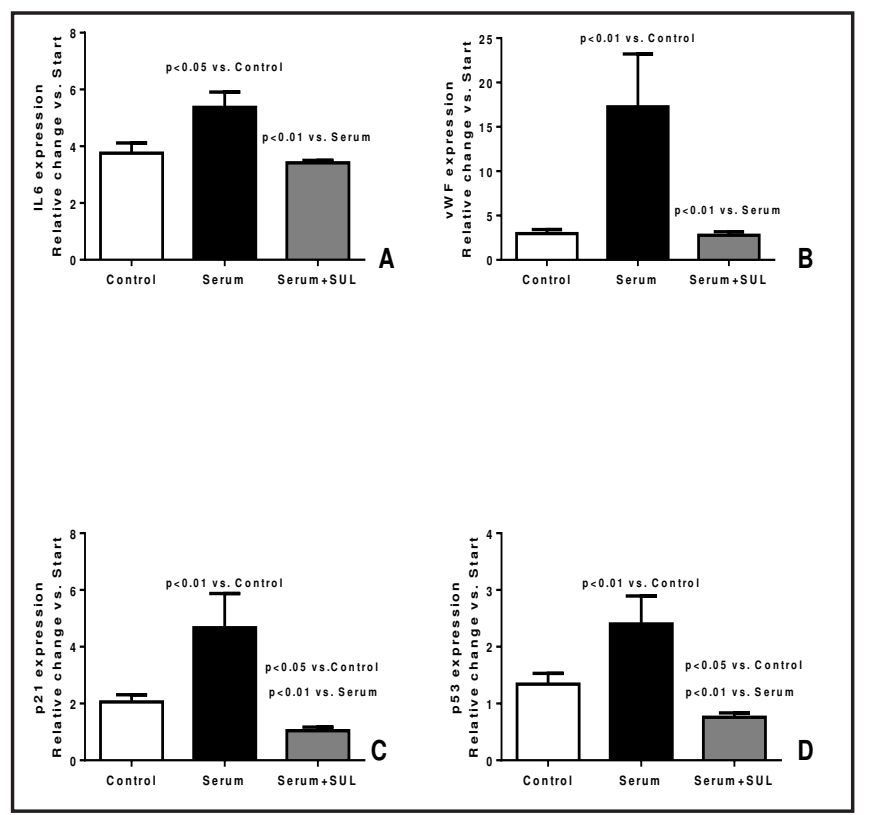

Fig. 4. Relative vs. start of the experiment, expression of IL6 (A) and vWF (B) p21 (C) and p53 (D) in cells undergoing replicative aging during 10 passages in control medium (Control), medium supplemented with PAD serum (Serum) or PAD serum and Sulodexide (Serum + Sul).

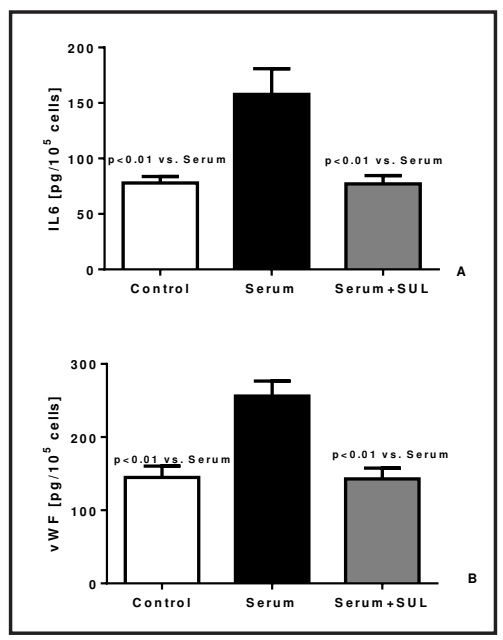

Fig. 5. Secretion of IL6 (A) and vWF (B) after 10 weeks of replicative aging of HAEC in control medium (Control), in medium with PAD serum (Serum) or in medium with PAD serum and Sulodexide (Serum + SUL).

group was highest, as compared to control $(+78 \%, \mathrm{p}<0.01)$ and the Sulodexide group $(+80 \%$, $\mathrm{p}<0.01$ ) (Fig. 5).

\section{Discussion}

Aging of the endothelial cells is an important factor contributing to the progression of atherosclerosis due to the development in these cells of the senescence-associated secretory phenotype [21]. Previously, we found that already short, lasting 24 hours exposure of human aortic endothelial cells to PAD serum induces the inflammatory reaction [16]. 
The proinflammatory phenotype has been described in the arterial endothelial cells from healthy older individuals, which suggests that cellular senescence of the endothelial cells may promote such a reaction [22]. The results of our present study suggest that chronic exposure of HAEC undergoing replicative aging to PAD serum accelerates the development of their senescence-associated secretory phenotype, reduces their ability to grow, as well as results in increased expression of genes p21 and p53 promoting cellular senescence. The increased expression of p53 genes observed in our study may reflect telomeres shortening in the aging endothelial cells, which may contribute to the progression of atherosclerosis $[23,24]$. The expression of p21 genes was also increased, which together with the increased activity of p53 genes, shortens the lifespan of the endothelial cells [25].

Stronger pro-inflammatory and pro-aging genes expression, secretory pattern and inhibition of HAEC growth exposed to the PAD serum maybe due to multiple pathomechanisms. Various factors present in the serum of patients with PAD such as dyslipidemia, intravascular inflammatory mediators and oxidative factors, can contribute to aging of the endothelial cells and their dysfunction $[26,27]$. There are various pharmacological approaches to prevent or at least reduce endothelial senescence and its contribution to the progression of atherosclerosis, including the use of ACE inhibitors, beta blockers, antioxidant agents, calcium channel blockers and statins [11]. Disorders within the endothelial glycocalyx reflected by a deficient amount of glycosaminoglycans or their altered structure may predispose patients to the progression of atherosclerotic changes [12]. Previously we found that sulodexide slows the senescence of the human venous endothelial cells undergoing replicative aging in standard culture conditions [15], and in the presence of serum from patients with chronic venous insufficiency [28]. The results from our study confirm that sulodexide also decreases senescence of aortic endothelial cells chronically exposed to PAD serum. We suggest that the beneficial effect of sulodexide in patients with peripheral artery diseases [29] may be caused not only by its direct antiinflammatory action in HAEC [16] but also due to the antisenescent effect in these cells.

The results from the present study confirm that sulodexide slows the progression of HAEC senescence, which in consequence results in reduced release of the inflammatory IL6 and prothrombotic factor vWF. All these effects may translate into slower progression of atherosclerosis. An interesting finding was the strong suppression by Sulodexide of p21 and p53 activity in HAEC, which was even more profound than in the control group. It was shown that telomere dysfunction, DNA damage or genomic instability can trigger cell senescence via the p53/p21 pathway [27]. Activation of that pathway, as was shown in our study, may be blocked by Sulodexide. In another study heparin sulfation appeared to be essential for prevention of cellular senescence and that effect was linked with inhibition of p53/p21 pathway [30]. This may suggest that many beneficial effects of Sulodexide in clinical practice may be due to its antisenescent activity.

The results from our studies, together with our previous findings [16], suggest that sulodexide which is a mixture of the natural glycosaminoglycans present in the endothelial glycocalyx, has a pleiotropic effect on arterial endothelial cells. It inhibits the senescence of the arterial endothelial cells, which in consequence decreases intravascular inflammation and the thrombogenic properties of plasma. All these effects may slow the progression of atherosclerotic changes in the arteries. We do not know if the effect of sulodexide on the aortic endothelial cells, as described in the present paper, is the same in other parts of the arterial system i.e.in the coronary vessels. Therefore, further experimental studies should be performed to evaluate the action of that drug on endothelial cells from other arterial vessels. The efficiency of sulodexide as a drug slowing the progression of atherosclerosis should also be further evaluated in clinical trials.

\section{Acknowledgements}

Study was supported by grant from Poznan University of Medical Sciences and grant IUVENTUS Plus 0733/IP1/2016/74 from the Ministry of Science and Higher Education. 


\section{Cellular Physiology Cell Physiol Biochem 2018;45:2225-2232 \begin{tabular}{l|l} 
and Biochemistry Published onlIne: March 15, 2018 & $\begin{array}{l}\text { (c) } 2018 \text { The Author(s). Published by S. Karger AG, Basel } \\
\text { www.karger.com/cpb }\end{array}$
\end{tabular}}

\section{Disclosure Statement}

Dr K. Jasinska - Suminska is an employee of Alfa Wassermann Polska.

\section{References}

$>1$ Tesauro M, Mauriello A, Rovella V, Annicchiarico-Petruzzelli M, Cardillo C, Melino G, Di Daniele N: Arterial ageing: from endothelial dysfunction to vascular calcification. J Intern Med 2017;281:471-482.

-2 Paneni F, Diaz Cañestro C, Libby P, Lüscher TF, Camici GG: The Aging Cardiovascular System: Understanding It at the Cellular and Clinical Levels. J Am Coll Cardiol 2017;69:1952-1967.

- Hayflick L, Moorhead PS: The serial cultivation of human diploid cell strains. Exp Cell Res 1961;25: 585621.

4 Harley CB, Futcher AB, Greider CW: Telomeres shorten during ageing of human fibroblasts. Nature 1990;345:458-460.

5 Coppé JP, Patil CK, Rodier F, Sun Y, Muñoz DP, Goldstein J, Nelson PS, Desprez PY, Campisi J: Senescenceassociated secretory phenotypes reveal cell-nonautonomous functions of oncogenic RAS and the p53 tumor suppressor. PLoS Biol 2008;6:2853-2868.

6 Liao P, Yang D, Liu D, Zheng Y: GLP-1 and Ghrelin attenuate high glucose/high lipid-induced apoptosis and senescence of human microvascular endothelial cells. Cell Physiol Biochem 2017:44:1842-1855.

-7 Kim MY, Kang ES, Ham SA, Hwang JS, Yoo TS, Lee H, Paek KS, Park C, Lee HT, Kim JH, Han CW, Seo HG: The PPAR $\delta$-mediated inhibition of angiotensin II-induced premature senescence in human endothelial cells is SIRT1-dependent. Biochem Pharmacol 2012;84:1627-1634.

-8 Kurz DJ, Decary S, Hong Y, Trivier E, Akhmedov A, Erusalimsky JD: Chronic oxidative stress compromises telomere integrity and accelerates the onset of senescence in human endothelial cells. J Cell Sci 2004;117:2417-2426.

-9 Warboys CM, de Luca A, Amini N, Luong L, Duckles H, Hsiao S, White A, Biswas S, Khamis R, Chong CK, Cheung WM, Sherwin SJ, Bennett MR, Gil J, Mason JC, Haskard DO, Evans PC: Disturbed flow promotes endothelial senescence via a p53-dependent pathway. Arterioscler Thromb Vasc Biol 2014;34:985-995.

10 Minamino T, Miyauchi H, Yoshida T, Ishida Y, Yoshida H, Komuro: Endothelial cell senescence in human atherosclerosis: role of telomere in endothelial dysfunction. Circulation 2002;105:1541-1544.

11 Su JB: Vascular endothelial dysfunction and pharmacological treatment. World J Cardiol 2015;7:719-741.

12 Zeng Y: Endothelial glycocalyx as a critical signalling platform integrating the extracellular haemodynamic forces and chemical signalling. J Cell Mol Med 2017 doi: 10.1111/jcmm.13081.

-13 Stancu CS, Toma L, Sima AV: Dual role of lipoproteins in endothelial cell dysfunction in atherosclerosis. Cell Tissue Res 2012;349:433-446.

14 Williamson KA, Hamilton A, Reynolds JA, Sipos P, Crocker I, Stringer SE, Alexander YM: Age-related impairment of endothelial progenitor cell migration correlates with structural alterations of heparan sulfate proteoglycans. Aging Cell 2013;12:139-147.

15 Suminska-Jasinska K, Polubinska A, Ciszewicz M, Mikstacki A, Antoniewicz A, Breborowicz A: Sulodexide reduces senescence-related changes in human endothelial cells. Med Sci Monit 2011;17:CR222-226.

-16 Sosińska P, Baum E, Maćkowiak B, Maj M, Sumińska-Jasińska K, Staniszewski R, Bręborowicz A: Sulodexide Reduces the Proinflammatory Effect of Serum from Patients with Peripheral Artery Disease in Human Arterial Endothelial Cells. Cell Physiol Biochem 2016;40:1005-1012.

17 Ksiazek K, Winckiewicz M, Staniszewski R, Breborowicz A, Witowski J: Correlation between the donor age and the proliferative lifespan of human peritoneal mesothelial cells in vitro: is TGF-beta1 a link? Exp Gerontol 2007;42:840-843.

18 Ye J, Coulouris G, Zaretskaya I, Cutcutache I, Rozen S, Madden TL: Primer-BLAST: a tool to design targetspecific primers for polymerase chain reaction. BMC Bioinformatics DOI: 10.1186/1471-2105-13-134.

19 Livak KJ, Schmittgen TD: Analysis of relative gene expression data using real-time quantitative PCR and the 2(-Delta Delta C(T)) Method. Methods 2001;25:402-408.

20 Debacq-Chainiaux F, Erusalimsky JD, Campisi J, Toussaint O: Protocols to detect senescence-associated beta-galactosidase (SA-betagal) activity, a biomarker of senescent cells in culture and in vivo. Nat Protoc 2009:4:1798-1806. 


\section{Cellular Physiology Cell Physiol Biochem 2018;45:2225-2232

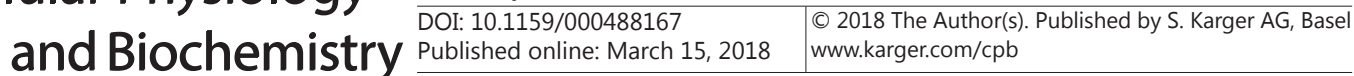

-21 Yin H, Pickering JG: Cellular Senescence and Vascular Disease: Novel Routes to Better Understanding and Therapy. Can J Cardiol 2016;32:612-623.

22 Donato AJ, Black AD, Jablonski KL, Gano LB, Seals DR: Aging is associated with greater nuclear NF kappa B, reduced I kappa B alpha, and increased expression of proinflammatory cytokines in vascular endothelial cells of healthy humans. Aging Cell 2008;7:805-812.

23 Beauséjour CM, Krtolica A, Galimi F, Narita M, Lowe SW, Yaswen P, Campisi J: Reversal of human cellular senescence: roles of the p53 and p16 pathways. EMBO J 2003;22:4212-4222.

-24 Tohru Minamino, Hideaki Miyauchi, Toshihiko Yoshida, Yasuo Ishida, Hideo Yoshida, Issei Komuro: Endothelial cell senescence in human atherosclerosis: role of telomere in endothelial dysfunction. Circulation 2002;105:1541-1544.

25 Hideyuki Miyauchi,1, Tohru Minamino,1, Kaoru Tateno, Takeshige Kunieda, Haruhiro Toko,Issei Komuro: Akt negatively regulates the in vitro lifespan of human endothelial cells via a p53/p21-dependent pathway. EMBO J 2004;23:212-220.

-26 Liu HH, Li JJ: Aging and dyslipidemia: a review of potential mechanisms. Ageing Res Rev 2015;19:43-52.

27 Donato AJ, Morgan RG, Walker AE, Lesniewski LA: Cellular and molecular biology of aging endothelial cells. J Mol Cell Cardiol 2015;89:122-135.

28 Urbanek T, Krasinski Z, Sumińska-Jasińska K, Baum E, Borej-Nowicka G, Begier-Krasińska B, Bręborowicz A: Sulodexide reduces the inflammatory reaction and senescence of endothelial cells in conditions involving chronic venous disease. Int Angiol 2016;35:140-147.

29 Coccheri S: Biological and clinical effects of sulodexide in arterial disorders and diseases. Int Angiol 2014;33:263-274.

- 30 Jung SH, Lee HC, Yu DM, Kim BC, Park SM, Lee YS, Park HJ, Ko YG, Lee JS: Heparan sulfation is essential for prevention of cellular senescence. Cell Death and Differentiation 2016:23:417-429. 